\title{
IMPLEMENTASI SISTEM PENGENDALIAN INTERN DAN PENGARUHNYA TERHADAP PENERIMAAN KAS PADA PERUSAHAAN AIR MINUM TIRTA MANGKALUKU (PAMTM) KOTA PALOPO
}

\author{
Aditoni \\ Prodi Akuntansi, Universitas Muhammadiyah Palopo \\ thonyadhy@gmail.com
}

\begin{abstract}
ABSTRAK
Penelitian ini bertujuan untuk memperoleh bukti empiris tentang implementasi sistem pengendalian intern dan pengaruhnya terhadap penerimaan kas pada perusahaan air minum tirta mangkaluku kota palopo. Variabel independen yang digunakan adalah sistem pengend alian intern, Variabel dependen yang digunakan adalah penerimaan kas. Populasi dalam penelitian adalah karyawan PAM TM. Kuesioner yang dibagikan kepada responden sebanyak 60 eksamplar dan kuesioner yang dikembalikan sebanyak 40 eksamplar. Penelitian ini menggunakan pendekatan kuantitatif dan menggunakan analisis regresi linear sederhana, dengan tambahan uji validitas dan uji reliabilitas. Hasil penelitian ini menunjukkan bahwa sistem pengendalian intern berpengaruh positif dan signifikan terhadap penerimaan kas pada Perusahaan Air Minum Tirta Mangkaluku kota Palopo. Ditunjukan dengan melihat nilai koefisien sistem pengendalian intern sebesar 0,649 sedangkan nilai signifikansinya adalah sebesar 0,000. Maka dapat disimpulkan bahwa sistem penegndalian intern mempunyai pengaruh positif dan signifikan terhadap penerimaan kas pada PAM TM kota Palopo. Untuk meningkatkan sistem pengendalian intern maka setiap karyawan harus diberi pemahaman mengenai tugas dan tanggunjawab masing-masing, serta komputer yang sudah ada lebih diperbarui agar lebih memudahkan aktivitas penerimaan kas.
\end{abstract}

Kata Kunci: pengendalian Intern, penerimaan kas

\section{ABSTRACT}

This study aims to obtain empirical evidence about the implementation of the internal control system and its effect on cash receipts at the Tirta Mangkaluku drinking water company in Palopo City. The independent variable used is the internal control system; the dependent variable used is cash receipts. The population in the study was PAM TM employees. The questionnaires were distributed to respondents as many as 60 exams, and the returned questionnaires were as many as 40 reviews. This study uses a quantitative approach and uses simple linear regression analysis, with the addition of validity and reliability testing. The results of this study indicate that the internal control system has a positive and significant effect on cash receipts at the Tirta Mangkaluku Drinking Water Company in Palopo. They were shown by looking at the coefficient value of the internal control system of 0.649, while the significance value of 0.000. It can be concluded that the internal control system has a positive and significant influence on cash receipts at PAM TM in Palopo city. Each employee must be given an understanding of their respective duties and responsibilities. The existing computer is more updated to make it easier to receive cash to improve the internal control system.

Keywords: Internal control, cash receipts

\section{PENDAHULUAN}

Latar belakang dalam penelitian ini didasarkan pada tiga poin utama yaitu pertama apa sih pentingnya dari penelitian ini?, kedua fenomena/masalah apa yang terjadi sehingga penelitian ini penting untuk diteliti dan ketiga masih terdapat perbedaan pendapat dari penelitian sebelumnya.

Pertama, pentingnya penelitian terletak dari tujuan SPI itu sendiri. Sistem pengendalian intern adalah bertujuan membantu agar para anggota organisasi dapat melaksanakan tugas dan 
tanggung jawabnya secara efektif, sehingga sistem dapat berjalan sesuai dengan yang diharapkan.

Kedua adapun fenomena yang menjadi pokok masalah dalam penelitian ini sehingga penelitian ini penting untuk diteliti, Pada tahun 2017 direkur PAM Tirta Mangkaluku kota Palopo mengungkapkan salah satu masalah yang dihadapi yaitu terjadinya gangguan sumber air baku akibat sistem pengendalian intern lemah, sehingga produksi air di Instalasi Pengolahan Air (IPA) menurun yang mengakibatkan air macet di wilayah layanan tertentu. Untuk memenuhi kebutuhan air pelanggan yang complain melalui hotline Pengaduan PAM maka truk tangki langsung mendistribusikan air dari slang ke rumahnya secara gratis. Layanan ini bersifat kasuistik. Jika macet air meluas dan terjadi cukup lama maka PAM akan mensosialisasikan schedule penggiliran kunjungan truk tangki. Kunjungan ini menerapkan pola antri atau door to door sesuai karakteristik kondisi. Layanan ini menyebabkan pelanggan rugi secara materiil dan immateriil. Kebijakan gratifikasi air tidak mampu menutupi pengorbanan waktu, tenaga, biaya dan beban psikis pelanggan Layanan ini juga merugikan PAM. Terjadi inefisiensi biaya operasional karena truk tangki bermobilitas tinggi saat door to door. Air juga terbuang sebagian saat slang truk tangki berpindah antar wadah penampungan pelanggan yang antri. Hilangnya potensi pendapatan atas air yang digratiskan juga tidak dapat dihindari. Pola antri dan door to door juga telah mengganggu kelancaran berlalu lintas. Apabila tetap diterapkan maka berpotensi terjadi kecelakaan kerja yang akan menimbulkan biaya langsung dan tidak langsung.

Ketiga perbedaan pendapat dari peneliti sebelumnya yaitu berdasarkan penelitian sebelumnya yang dilakukuan Penelitian mengenai sistem pengendalian intern yang dilakukan oleh Lamusu (2013) menyatakan bahwa sistem pengendalian intern berpengaruh positif dan signifikan terhadap pengelolaan keuangan daerah namun Syarifuddin (2010) menyatakan bahwa sistem pengendalian intern tidak berpengaruh signifikan terhadap pengelolaan keuangan keuangan daerah.

Berdasarkan judul dan uraian yang telah dikemukakan sbelumnya, terdapat fenomena yaitu temuan yang di dapatkan terkait sistem pengendalian inter lemah salah satu diantaranya adalah lemah dalam pengelolaan kas, serta adanya research gap dari penelitian terdahulu yang menunjukkan hasil yang berbeda-beda. Sehingga perlu diteliti kembal.:

Berdasarkan rumusan masalah yang telah diuraikan di atas maka tujuan dalam penelitian ini adalah Untuk mengetahui pengaruh Implementasi sistem pengendalian intern terhadap 
penerimaan kas pada Perusahaan Air Minum Tirta Mangkaluku (PAMTM) Kota Palopo.

\section{TINJAUAN PUSTAKA}

\section{Teori Coso}

Comite of Sponsoring Organizations of the Treadway commission (COSO) menerbitkan internal control - Integrated Framework tahun 1994 yang mengemukakan bahwa pengendalian internal merupakan pengendalian kegiatan (operasional) perusahaan yang dilakukan pemimpin perusahaan untuk mencapai tujuan secara efisien, yang terdiri dari kebijakan- kebijakan dan prosedur-prosedur yang ditetapkan untuk mencapai tujuan tertentu dari operasi perusahaan. Comite of Sponsoring Organizations of the Treadway commission (COSO) mengenalkan bahwa terdapat 5 (lima) komponen kebijakan dan prosedur yang didesain dan diimplementasikan untuk memberikan jaminan bahwa tujuan pengendlian intern dapat dicapai. Kelima komponen pengendalian intern tersebutadalah:

1. Lingkungan Pengendalian

Lingkungan pengendalian menurut COSO didefinisikan sebagai seperangkat standar, proses, dan struktur yang memberikan dasar untuk melaksanakan pengendalian internal diseluruh organisasi.

2. Penilaian Risiko

Penilaian risiko melibatkan proses yang dinamis dan interaktik untuk mengindetifikasi dan menilai resiko terhadap pencapaian tujuan. Resiko itu sendiri dipami sebagai suatu kemungkinan bahwa suatu peristiwa akan terjadi dan mempengaruhi pencapaian tujuan entitas, dan risiko terhadap pencapaian seluruh tujuan dari entitas dianggap relative terhadap toleransi risiko yang ditetapkan.

3. Informasi dan komunikasi

Informasi sangat penting bagi setiap entitas untuk melaksanakan tanggungjawab pengendalian internal guna mendukung pencapaian tujuannya. Informasi yang diperlukan manajemen adalah informasi berkualitas baik yang digunakan untuk mendukung fungsi komponen-komponen lain dari pengendalian internal.

4. Aktivitas Pengendalian

Menurut COSO aktivitas pengendalian adalah tindakan-tindakan yang ditetapkan melalui kebijakan dan prosedur yang membantu memastikan bahwa arahan 
manajemen untuk mengurangi risiko terhadap pencapaian tujuan.

5. Pemantauan

Pemantauan merupakan kegiatan evaluasi dengan beberapa bentuk apakah yang sifatnya berkelanjutan, terpisah ataupun kombinasi keduanya yang digunakan untuk memastikan apakah masing-masing dari lima komponen pengendalian internal mempengaruhi prinsip-prinsip dalam setiap komponen, ada dan berfungsi.

\section{Teori Stakeholder}

Teori stakeholder menjelaskan bahwa perusahaan harus memberikan manfaat bagi para stakeholdernya, tidak hanya beroperasi untuk pencapaian tujuannya. Stakeholder yang dimaksud adalah pemegang saham, kreditur, konsumen, supplier, pemerintah, masyarakat dan pihak lainnya yang ikut serta dalam proses pencapaian tujuan perusahaan. Dengan kata lain kemakmuran suatu perusahaan sangat bergantung kepada dukungan dari para stakeholdernya. Stakeholder diartikan sebagai pemangku kepentingan yaitu pihak atau kelompok yang berkepentingan, baik langsung maupun tidak langsung terhadap eksistensi atau aktivitas perusahaan, dan karenanya kelompok tersebut mempengaruhi dan dipengaruhi oleh perusahaan. Kelompok stakeholder inilah yang menjadi pertimbangan utama bagi perusahaan dalam mengungkapkan atau tidak mengungkapkan suatu informasi di dalam annual report (Puspitasari, 2017).

\section{Sistem Pengendalian Intern}

Menurut Rai (2008: 283), sistem pengendalian intern adalah kebijakan dan prosedur yang dirancang untuk memberikan keyakinan yang memadai bagi manajemen bahwa organisasi mencapai tujuan dan sasarannya. Sedangkan menurut Peraturan Pemerintah No.60 Tahun 2008 pengertian sistem pengendalian intern adalah proses yang integral pada tindakan dan kegiatan yang dilakukan secara terus menerus oleh pimpinan dan seluruh pegawai untuk memberikan keyakinan memadai atas tercapainya tujuan organisasi melalui kegiatan yang efektif dan efisien, keandalan pelaporan keuangan, pengamanan asset negara dan ketaatan terhadap peraturan perundang-undangan.

Menurut Mulyadi (2001:32), sistem adalah gabungan suatu sistem yang meliputi struktur organisasi, metode dan ukuran-ukuran yang dikoordinasikan untukmenjaga kekayaan rganisasi, mengecek ketelitian dan keandalan data akuntansi, mendorong efisiensi dan mendorong dipatuhinya kebijakan manajemen. 
Menurut Mulyadi (2001:163), suatu perusahaan menerapkan sistem pengendalian intern sebagai penunjang dalam menjalankan usahanya. Sistem tersebut disesuaikan dengan keadaan dan kondisi masing-masing perusahaan karena jenis dan bentuk perusahaan yang berbeda-beda. Sistem pengendalian intern yaitu suatu sistem yang meliputi struktur organisasi, metode dan ukuran-ukuran yang dikoordinasikan untuk menjaga kekayaan organisasi, mengecek ketelitian dan keandalan data akuntansi, mendorong efisiensi dan mendorong dipatuhinya kebijakan manajemen. tujuan sistem pengendalian intern dilihat dari definisi sistem pengendalian intern adalah: menjaga kekayaan organisasi, mengecek ketelitian dan keandalan data akuntansi, mendorong efisiensi, mendorong dipatuhinya kebijakan manajemen.

Menurut Mulyadi, 2001: 164, sistem pengendalian intern terhadap penerimaan kas yang meliputi struktur organisasi, metode dan ukuran-ukuran yang dikoordinasikan perusahaan, selain itu unsur-unsur pokok sistem pengendalian intern meliputi: organisasi yang memisahkan tanggung jawab dan wewenang secara tegas, sistem otorisasi dan prosedur pencatatan, praktik yang sehat, dan karyawan yang mutunya sesuai dengan tanggung jawab. Menurut tujuannya, sistem pengendalian intern tersebut dapat dibagi menjadi dua macam: pengendalian intern akuntansi dan pengendalian intern administratif.

\section{METODE PENELITIAN}

\section{Jenis dan Sumber Data}

Jenis dan sumber data dalam penelitian ini adalah data kuantitatif yang mengunakan hasil dari kuesioner. Sumber data yang digunakan dalam penelitian ini adalah data primer, yaitu berupa jawaban responden terhadap pernyataan yang terdapaat dalam kuesioner yang dikumpulkan dari Perusahaan air minum tirta mangkaluku kota palopo. Adapun sumber lain dalam penelitian ini yaitu dari artikel, jurnal, skripsi dan tesis yang diterbitkan dan dipublikasikan serta buku-buku yang berkaitan dengan topik penelitian.

\section{Populasi dan Sampel}

Populasi adalah keseluruhan kelompok orang, kejadian, atau hal minat yang ingin peneliti teliti/dikaji. Populasi dari penelitian ini adalah karyawan perusahaan air minum tirta mangkaluku (PAM TM) kota palopo.

Sampel adalah sebagian dari populasi, sampel terdiri atas sejumlah anggota yang dipilih dari populasi. Sampel dari penelitian ini adalah karyawan perusahaan air minum tirta mangkaluku 
(PAM TM) kota palopo sebanyak 40 orang.

Pengumpulan Data Primer Penelitian

\begin{tabular}{|c|l|c|c|}
\hline No. & \multicolumn{1}{|c|}{ Keterangan } & $\begin{array}{c}\text { Jumlah } \\
\text { Kuesioner }\end{array}$ & Presentase (\%) \\
\hline 1 & Distribusi kuesioner & 60 & $100 \%$ \\
\hline 2 & Kuesioner Kembali & 40 & $65 \%$ \\
\hline 3 & Kuesioner cacat/tidak kembali & 20 & $35 \%$ \\
\hline 4 & Kuesioner yang dapat diolah & 40 & $65 \%$ \\
\hline n sampel yang kembali $=40$ & & \\
\hline Responden rate $=40 \times 100 \%$ & & \\
\hdashline & & \\
\hline
\end{tabular}

Sumber: Data Primer yang diolah (2019)

Sebanyak 40 karyawan yang bekerja di Perusahaan Air Minum Tirta Mangkaluku kota Palopo berhasil dikumpulkan sebagai responden dalam penelitian ini.

Tabel Deskripsi Responden berdasarkan Jenis Kelamin

\begin{tabular}{|c|c|c|c|}
\hline NO & $\begin{array}{c}\text { Jenis } \\
\text { Kelamin }\end{array}$ & $\begin{array}{c}\text { Jumlah } \\
\text { Responden }\end{array}$ & Persentase \\
\hline 1 & Laki-Laki & 28 & $57 \%$ \\
\hline 2 & Perempuan & 12 & $43 \%$ \\
\hline \multicolumn{2}{|c|}{ Jumlah } & 40 & 100 \\
\hline
\end{tabular}

Sumber: Data Primer Diolah 2019

\section{Uji Validitas dan Uji Reliabilitas}

Validitas atau tingkat ketepatan adalah kemampuan suatu alat ukur untuk untuk mengukur apa yang ingin diukur. Setelah data dikumpulan, maka pengujian validitas dilakukan dengan mengkorelasikan skor-skor setiap item pertanyaan dengan skor total, Sapar (2017:56).

Reliabilitas adalah tingkat kepenelitian yang menunjukkan sejauh mana suatu alat ukur dapat dipercaya. Bila suatu alat pengukur dipakai dua kali untuk mengukur gejala yang sama dan hasil pengukuran yang diperoleh relatif konsisten, maka alat pengukur tersebut reliabel Sapar (2017:60).

Pengujian validitas data dalam penelitian ini dilakukan dengan cara statistik yaitu menghitung korelasi antara masing-masing pertanyaan dengan skor total dengan menggunakan metode product moment pearson correlation. Data dinyatakan valid jika nilai $r$ hitung yang merupakan nilai item dari Corrected Item-Total Correlation > dari r tabel pada signifikansi 0,05 (5\%). Berikut ini disajikan validitas dari masing-masing variabel pada tabel 
berikut:

Hasil Uji Validitas Penerimaan Kas

\begin{tabular}{|c|c|c|c|}
\hline Instrumen & $\begin{array}{c}\text { r } \\
\text { hitung }\end{array}$ & r tabel & $\begin{array}{c}\text { Keteran } \\
\text { gan }\end{array}$ \\
\hline $\begin{array}{c}\text { Pernyataan } \\
\text { Y.1 }\end{array}$ & 0,793 & 0,3044 & Valid \\
\hline $\begin{array}{c}\text { Pernyataan } \\
\text { Y.2 }\end{array}$ & 0,826 & 0,3044 & Valid \\
\hline $\begin{array}{c}\text { Pernyataan } \\
\text { Y.3 }\end{array}$ & 0,760 & 0,3044 & Valid \\
\hline $\begin{array}{c}\text { Pernyataan } \\
\text { Y.4 }\end{array}$ & 0,764 & 0,3044 & Valid \\
\hline
\end{tabular}

\begin{tabular}{|c|c|c|c|}
\hline $\begin{array}{c}\text { Pernyataan } \\
\text { Y.5 }\end{array}$ & 0,637 & 0,3044 & Valid \\
\hline $\begin{array}{c}\text { Pernyataan } \\
\text { Y.6 }\end{array}$ & 0,558 & 0,3044 & Valid \\
\hline $\begin{array}{c}\text { Pernyataan } \\
\text { Y.7 }\end{array}$ & 0,614 & 0,3044 & Valid \\
\hline $\begin{array}{c}\text { Pernyataan } \\
\text { Y.8 }\end{array}$ & 0,849 & 0,3044 & Valid \\
\hline $\begin{array}{c}\text { Pernyataan } \\
\text { Y.9 }\end{array}$ & 0,820 & 0,3044 & Valid \\
\hline $\begin{array}{c}\text { Pernyataan } \\
\text { Y.10 }\end{array}$ & 0,817 & 0,3044 & Valid \\
\hline $\begin{array}{c}\text { Pernyataan } \\
\text { Y.11 }\end{array}$ & 0,700 & 0,3044 & Valid \\
\hline $\begin{array}{c}\text { Pernyataan } \\
\text { Y.12 }\end{array}$ & 0,897 & 0,3044 & Valid \\
\hline $\begin{array}{c}\text { Pernyataan } \\
\text { Y.13 }\end{array}$ & 0,827 & 0,3044 & Valid \\
\hline $\begin{array}{c}\text { Pernyataan } \\
\text { Y.14 }\end{array}$ & 0,468 & 0,3044 & Valid \\
\hline \multicolumn{2}{|c|}{ Sumber- Data Primer Diolah 2019 }
\end{tabular}

Hasil pengujian validitas menunjukkan bahwa semua item didalam variabel penerimaan kas yang diuji dinyatakan valid karena nilai Corrected Item-Correlation > dari $\mathrm{r}$ tabel pada signifikan 0,05 (5\%).

Hasil Uji Validitas Sistem Pengendalian Intern

\begin{tabular}{|c|c|c|c|}
\hline Instrumen & $\begin{array}{c}\text { r } \\
\text { hitung }\end{array}$ & r tabel & $\begin{array}{c}\text { Keteran } \\
\text { gan }\end{array}$ \\
\hline $\begin{array}{c}\text { Pernyataan } \\
\text { X.1 }\end{array}$ & 0,811 & 0,3044 & Valid \\
\hline $\begin{array}{c}\text { Pernyataan } \\
\text { X.2 }\end{array}$ & 0,917 & 0,3044 & Valid \\
\hline $\begin{array}{c}\text { Pernyataan } \\
\text { X.3 }\end{array}$ & 0,860 & 0,3044 & Valid \\
\hline $\begin{array}{c}\text { Pernyataan } \\
\text { X.4 }\end{array}$ & 0,789 & 0,3044 & Valid \\
\hline $\begin{array}{c}\text { Pernyataan } \\
\text { X.5 }\end{array}$ & 0,882 & 0,3044 & Valid \\
\hline $\begin{array}{c}\text { Pernyataan } \\
\text { X.6 }\end{array}$ & 0,822 & 0,3044 & Valid \\
\hline $\begin{array}{c}\text { Pernyataan } \\
\text { X.7 }\end{array}$ & 0,860 & 0,3044 & Valid \\
\hline $\begin{array}{c}\text { Pernyataan } \\
\text { X.8 }\end{array}$ & 0,781 & 0,3044 & Valid \\
\hline $\begin{array}{c}\text { Pernyataan } \\
\text { X.9 }\end{array}$ & 0,744 & 0,3044 & Valid \\
\hline
\end{tabular}




\begin{tabular}{|c|c|c|c|}
\hline $\begin{array}{c}\text { Pernyataan } \\
\text { X.10 }\end{array}$ & 0,715 & 0,3044 & Valid \\
\hline $\begin{array}{c}\text { Pernyataan } \\
\text { X.11 }\end{array}$ & 0,890 & 0,3044 & Valid \\
\hline $\begin{array}{c}\text { Pernyataan } \\
\text { X.12 }\end{array}$ & 0,689 & 0,3044 & Valid \\
\hline $\begin{array}{c}\text { Pernyataan } \\
\text { X.13 }\end{array}$ & 0,822 & 0,3044 & Valid \\
\hline $\begin{array}{c}\text { Pernyataan } \\
\text { X.14 }\end{array}$ & 0,608 & 0,3044 & Valid \\
\hline $\begin{array}{c}\text { Pernyataa } \\
\text { n X.15 }\end{array}$ & 0,626 & 0,3044 & Valid \\
\hline $\begin{array}{c}\text { Pernyataa } \\
\text { n X.16 }\end{array}$ & 0,802 & 0,3044 & Valid \\
\hline $\begin{array}{c}\text { Pernyataa } \\
\text { n X.17 }\end{array}$ & 0,811 & 0,3044 & Valid \\
\hline $\begin{array}{c}\text { Pernyataa } \\
\text { n X.18 }\end{array}$ & 0,821 & 0,3044 & Valid \\
\hline $\begin{array}{c}\text { Pernyataa } \\
\text { n X.19 }\end{array}$ & 0,852 & 0,3044 & Valid \\
\hline $\begin{array}{c}\text { Pernyataa } \\
\text { n X.20 }\end{array}$ & 0,358 & 0,3044 & Valid \\
\hline \multicolumn{4}{|c|}{ Sumber: Data yang diolah di tahun 2019 }
\end{tabular}

Hasil pengujian validitas menunjukkan bahwa semua item didalam variabel sistem pengendalian intern yang diuji dinyatakan valid karena nilai Corrected Item-Correlation > dari $r$ tabel pada signifikan $0,05(5 \%)$.

\section{Uji Reliabilitas Data}

Reliabilitas adalah alat ukur untuk mengukur suatu kuesioner yang merupakan indikator dari variabel. Suatu kuesioner dikatakan reliabel jika jawaban dari responden itu stabil dari waktu ke waktu. Nilai ketentuan untuk mengukur realibilitas dengan uji statistik Cronbach Alpha $(\alpha)$. Suatu konstruk dinyatakan reliabel jika memiliki Conbach Alpha > 0,60.

Hasil Uji Reliabilitas

\begin{tabular}{|c|c|c|c|}
\hline Variabel & $\begin{array}{c}\text { Alpha } \\
\text { Cronbach's }\end{array}$ & $\begin{array}{c}\text { Batas } \\
\text { Reliabilitas }\end{array}$ & Keterangan \\
\hline Penerimaan Kas (Y) & 0,903 & 0,60 & Reliabel \\
\hline $\begin{array}{c}\text { Sistem Pengendalian Intern } \\
(\mathrm{X})\end{array}$ & 0,964 & 0,60 & Reliabel \\
\hline
\end{tabular}

Sumber: Data primer diolah SPSS

Dari tabel diatas hasil pengujian reliabilitas menunjukkan variabel Penerimaan Kas, dan Sistem Pengendalian Intern memiliki cronbach alpha > 0,60 hal ini menunjukkan bahwa semua variabel dalam penelitian ini reliabel.

\section{Hasil Uji Regresi Sederhana}

Metode regresi linear sederhana ini di maksudkan untuk mengetahui besar tingkat pengaruh antara sistem pengendalian intern dengan penerimaan kas, untuk itu penulis sajikan hasil uji regresi linear sderana berdasarkan tabel berikut; 


\begin{tabular}{|l|l|l|l|l|l|}
\hline \multirow{2}{*}{ Model } & \multicolumn{2}{|l|}{ Unstandardized coefficients } & $\begin{array}{l}\text { Standardized } \\
\text { Coefficients }\end{array}$ & \multirow{2}{*}{$\mathrm{t}$} & Sig \\
\cline { 2 - 4 } & $\mathrm{B}$ & Std Eror & Betz & & \\
\hline 1 (Constant) & 3,331 & 7,803 & & 427 & 572 \\
SPI & .649 &, 059 &, 872 & 10,973 & .000 \\
& & & & & \\
\hline
\end{tabular}

Sumber: Data Primer Diolah 2019

Pada output ini, dikemukakan nilai koefisien dari persamaan regresi. Dalam kasus ini, persamaan regresi sederhana yang digunakan adalah :

$$
\begin{aligned}
& Y=\mathbf{a}+\mathbf{b} X \\
& Y=\mathbf{3 , 3 3 1}+\mathbf{0 , 6 4 9} X
\end{aligned}
$$

Dimana:

$\mathrm{Y}=$ Penerimaan Kas

$\mathrm{X}=$ Sistem pengendalian Intern

Dari output di dapatkan model persamaan regresi: Koefisien-koefisien persamaan regresi linear sederhana diatas dapat diartikan koefisien regresi untuk konstan sebesar 331 menunjukkan bahwa jika variabel Sistem Pengendalian Intern bernilai nol atau tetap maka akan meningkatkan penerimaan kas sebesar 3,331 satuan Variabel Sistem Pengendalian Intern 0,649 menunjukkan bahwah jika variabel Sistem Pengendalian Intern meningkat satu satuan maka akan meningkatkan Penerimaan Kas sebesar 0 ,649 satuan atau sebesar 64,9\%.

\section{Hasil Uji Determinasi $\left(\mathbf{R}^{2}\right)$}

Koefesien uji determinasi $\left(R^{2}\right)$ bertujuan untuk mengetahui seberapa besar kemampuan variabel independen sistem pengendalian intern mampu menjelaskan variabel dependen penerimaan kas. Berikut ini hasil uji koefisien determinasi $\left(\mathrm{R}^{2}\right)$.

\begin{tabular}{|l|c|c|c|c|}
\hline $\begin{array}{l}\text { Mod } \\
\text { el }\end{array}$ & $\mathrm{R}$ & $\begin{array}{c}\text { Squa } \\
\text { re }\end{array}$ & $\begin{array}{c}\text { Adjust } \\
\text { ed R } \\
\text { Square }\end{array}$ & $\begin{array}{c}\text { Std. } \\
\text { Error } \\
\text { of the } \\
\text { Estima } \\
\text { te }\end{array}$ \\
\hline 1 & $\begin{array}{rlr}.87 \\
2^{\mathrm{a}}\end{array}$ & .760 & .754 & $\begin{array}{r}6.4443 \\
7\end{array}$ \\
\hline \multicolumn{4}{|c|}{ Sumber: Data Primer Diolah 2019 }
\end{tabular}

Berdasarkan tabel diatas diketahui nilai Rsquare sebesar 0,760 (76,0\%). Hal ini membuktikan bahwa pengaruh sistem pengendalian intern terhadap peneimaan kas sesuai dengan interval 
koefesien yaitu Uji Adjusted $R^{2}$ digunakan untuk mengetahui seberapa besar sumbangan secara simultan variabel sistem pengendalian intern terhadap penerimaan kas. Pengujian ini dilakukan dengan melihat nilai R Square. Hasil Uji Adjusted $R^{2}$ dapat dilihat pada tabel diketahui bahwa nilai Adjusted $R^{2}$ adalah sebesar 0,754. Hal ini berarti bahwa sebesar 75,4 \% variabel dependen atau penerimaan kas dipengaruhi oleh variabel independen yaitu, sistem pengendalian intern, sedangkan sisanya yaitu sebesar $24,6 \%$ dijelaskan oleh faktor- faktor lain yang dapat mempengaruhi penerimaan kas.

\section{Hasil Uji Hipotesis (Uji t)}

Pengujian hipotesis secara parsial dimaksudkan untuk mengetahui ada atau tidaknya pengaruh variabel bebas secara parsial terhadap variabel terikat. Hasil dalam pengujian ini adalah.

\begin{tabular}{|c|c|c|c|c|c|c|}
\hline \multirow{2}{*}{\multicolumn{2}{|c|}{ Model }} & \multicolumn{2}{|c|}{ Unstandardized Coefficients } & \multirow{2}{*}{$\begin{array}{c}\text { Standardized } \\
\text { Coefficients }\end{array}$} & \multirow[b]{2}{*}{$\mathrm{t}$} & \multirow[b]{2}{*}{ Sig. } \\
\hline & & $\mathrm{B}$ & Std. Error & & & \\
\hline \multirow[t]{2}{*}{1} & (Constant) & 3.331 & 7.803 & & .427 & .672 \\
\hline & $\begin{array}{l}\text { sistem pengendalian } \\
\text { internal }\end{array}$ & .649 & .059 & .872 & 10.973 & .000 \\
\hline
\end{tabular}

Dependent Variable: penerimaan kas

Sumber: Data diolah SPSS

Hasil pengujian menunjukan nilai signifikan sistem pengendalian intern yaitu sebesar $0,000<$ 0,05 dan nilai $t_{\text {hitung }}$ sebesar 10,973>t tabel sebesar 1,684 sehingga dapat di buktikan bahwa variabel sistem pengendalian intern berpengaruh signifikan terhadap penerimaan kas atau dengan kata lain yang menyatakan bahwa sistem pengendalian intern berpengaruh terhadap penerimaan kas.

\section{HASIL DAN PEMBAHASAN}

Diduga bahwa Implementasi Sistem Pengendalian Intern berpengaruh positif dan signifikan terhadap penerimaan kas pada Perusahaan Air Minum Tirta Mangkaluku (PAM TM) kota Palopo.

Pengujian dilakukan melalui signifikansi koefisien regresi variabel sistem pengendalian intern. Sistem pengendalian intern memiliki nilai koefisien sebesar 0,649 sedangkan nilai signifikansinya adalah sebesar 0,000. Hasil tersebut dapat diartikan bahwa nilai signifikansi lebih kecil dari 0,05, ini berarti pengaruh sistem pengendalian intern terhadap penerimaan kas signifikan, atau ada pengaruh sistem pengendalian intern terhadap penerimaan kas. Koefisien- 
koefisien persamaan regresi linear sederhana diatas dengan nilai Beta sebesar 0.872 dapat diartikan koefisien regresi untuk konstan sebesar 3,331 menunjukkan bahwa jika variabel Sistem Pengendalian Intern bernilai nol atau tetap maka akan meningkatkan penerimaan kas sebesar 3,331 satuan variabel sistem pengendalian intern 0,649 menunjukkan bahwah jika variabel sistem pengendalian intern meningkat 1 satuan maka akan meningkatkan penerimaan kas sebesar 0,649 satuan atau sebesar 64,9\%.

Sedangkan nilai Adjusted $R^{2}$ adalah sebesar 0,754. Hal ini berarti bahwa sebesar 75,4 \% variabel dependen atau penerimaan kas dipengaruhi oleh variabel independen yaitu, sistem pengendalian intern, sedangkan sisanya yaitu sebesar 24,6\% dijelaskan oleh faktor-faktor lain yang dapat mempengaruhi penerimaan kas.

Pembahasan dalam penelitian ini menggunakan variabel dependen yaitu peneriman kas dan variabel independen yaitu sistem pengendalian intern, sebagai berikut: Hasil uji hipotesis $\mathrm{H}_{1}$ di terima yang berbunyi implementasi sistem pengendalian intern berpengaruh signifikan terhadap penerimaan kas pada Perusahaan Air Minum Tirta Mangkaluku kota Palopo.

Hasil penelitian ini sejalan dengan teori COSO yang dikutip oleh Hesty (2013:11) Pengendalian internal adalah suatu proses, melibatkan seluruh anggota organisasi, dan memiliki tujuan utama yaitu efektivitas, efesiensi operasional, kehandalan laporan keuangan, dan kepatuhan atas hukum dan peraturan yang berlaku. Artinya, dengan adanya pengendalian internal maka diharapkan perusahaan dapat bekerja secara efektif dan efisien, penyajian informasi dapat diyakini kebenarannya dan semua pihak akan mematuhi semua peraturan dan kebijakan yang ada dengan dipatuhinya peraturan dan kebijakan maka penyimpangan dapat dihindari.

Hasil penelitian ini sejalan dengan teori Mulyadi (2016), setiap perusahaan dituntut untuk menerapkan sistem akuntansi yang sesuai dengan kondisi masing-masing perusahaan salah satu sistem yang digunakan oleh perusahaan adalah sistem akuntansi penerimaan dan pengeluaran kas." Sistem akuntansi adalah organisasi formulir, catatan, dan laporan yang dikoordinasi sedemikian rupa sehingga untuk menyediakan informasi keuangan yang dibutuhkan oleh manajemen guna memudahkan pengelolaan perusahaan”

Hasil penelitian ini sejalan dengan teori Sari (2014), salah satu sistem yang digunakan oleh perusahaan adalah sistem akuntansi penerimaan dan pengeluaran kas "Dalam sistem penerimaan dan pengeluaran kas diperlukan adanya prosedur yang baik yang nantinya akan 
sesuai dengan kebijakan manajemen yang telah ditetapkan. Penerimaan dan pengeluaran kas yang dilakukan diluar prosedur yang telah ditentukan, akan menimbulkan terjadinya penyelewengan, pencurian, dan penggelapan kas. Dapat disimpulkan bahwa semakin semakin baik prosedur penerimaan dan pengeluaran kas yang dilakukan perusahaan, maka akan semakin dapat dipercaya besarnya akun kas yang dilaporkan pada laporan keuangan perusahaan tersebut di samping itu, tingkat penyelewengan dan penggelapan kas akan mudah ditelusuri. Apalagi masalah pengeluaran kas, dimana telah diketahui kas adalah masalah yang paling rawan dan resiko hilangnya paling tinggi”

Hasil penelitian ini sejalan dengan teori Baridwan (2012:3), menjelaskan bahwa sistem adalah suatu kerangka dari prosedur-prosedur yang saling berhubungan yang disusun sesuai dengan suatu skema yang menyeluruh, untuk melaksanakan suatu kegiatan atau fungsi utama dari perusahaan. Jika dalam pelaksanaan prosedur ada yang tidak berjalan dengan semestinya, maka akan berpengaruh terhadap kinerja perusahaan. Setiap perusahaan sangat bergantung pada sistem informasi manajemennya agar dapat bertahan di tengah persaingan. Informasi dapat digunakan sebagai bahan pertimbangan dalam pengambilan keputusan oleh perusahaan, salah satu informasi yang sangat dibutuhkan oleh manajemen perusahaan adalah informasi akuntansi.

Hasil penelitian ini sejalan dengan teori Rai (2008: 283), sistem pengendalian intern adalah kebijakan dan prosedur yang dirancang untuk memberikan keyakinan yang memadai bagi manajemen bahwa organisasi mencapai tujuan dan sasarannya. Sedangkan menurut Peraturan Pemerintah No.60 Tahun 2008 pengertian sistem pengendalian intern adalah proses yang integral pada tindakan dan kegiatan yang dilakukan secara terus menerus oleh pimpinan dan seluruh pegawai untuk memberikan keyakinan memadai atas tercapainya tujuan organisasi melalui kegiatan yang efektif dan efisien, keandalan pelaporan keuangan, pengamanan asset negara dan ketaatan terhadap peraturan perundang-undangan.

Hasil penelitian ini sejalan dengan teori Reeve et al (2013:387), mendefinisikan Pengendalian internal secara luas diartikan sebagai prosedur-prosedur serta proses-proses yang digunakan perusahaan untuk melindungi aset perusahaan, mengolah informasi secara akurat, serta memastikan kepatuhan hukum dan peraturan yang berlaku. Libby, Libby,\& Short (2008:298), mendefinisikan pengendalian internal adalah proses yang digunakan perusahaan untuk mengamankan aset perusahaan dan member jaminan yang memadai terkait dengan reliabilitas pelaporan keuangan perusahaan, efisiensi dan efektivitas operasi perusahaan,dan kesesuaian 
operasi perusahaan dengan aturan dan regulasi yang berlaku.

Hasil penelitian ini sejalan dengan teori Wilopo (2006: 05), keefektifan pengendalian intern dapat mengurangi terjadinya kecurangan akuntansi. Apabila pengendalian intern lemah, maka akan mengakibatkan tidak terjaminnya kekayaan perusahaan. Akibatnya, informasi akuntansi tidak efisien, tidak dapat dipercaya, dan tidak dapat dipatuhinya kebijaksanaan manajemen yang ditetapkan serta kegiatan- kegiatan operasional perusahaan menjadi tidakefektif. Krismiaji, (2015:213), Pengendalian (control) adalah proses mempengaruhi atau mengarahkan aktivitas sebuah objek, organisasi, atau sistem. Tujuan dilakukan pengendalian adalah untuk mencegah timbulnnya kerugian bagi sebuah organisasi.

Hasil penelitian ini sejalan dengan teori Sumarso SR (2002: 52), pada dasarnya untuk dapat menghasilkan sistem pengendalian kas, maka penerimaan harus dilakukan dengan cek, penerimaan-penerimaan kas, pemisahan tugas antara yang berhak menyetujui penerimaan kas, yang menyimpan uang kas, dan melakukan penerimaan serta yang mencatatat penerimaan kas. Menurut Arens and Loebbecke (2001) tujuan indikator dalam memeriksa penerimaan kas, yaitu: Existence (Keabsahan), Completeness (Kelengkapan), Accuracy (Ketepatan), Calcification (Kalsifikasi), Timing (Ketepatan Waktu), serta Posting and Summarization (Posting dan Peringkasan).

Hasil penelitian ini sejalan dengan teori Bodnar dan Hoopwood (2006: 3), menyatakan bahwa sistem merupakan sekumpulan sumber daya yang saling terkait untuk mencapai satu tujuan. Prosedur adalah operasi tulis menulis yang berurutan yang biasanya menyangkut beberapa orang dalam satu atau beberapa bagian, guna menjamin keseragaman pelaksanaan suatu transaksi perusahaan yang berulang-ulang. (R. Soemita Adi Kusuma) Warren, Reeve, Fees (2005:234), Sistem akuntansi adalah metode untuk mengumpulkan, mengklarifikasikan, mengikhtisarkan, dan melaporkan informasi operasi dan keuangan sebuah perusahaan.

Hasil penelitian ini sejalan dengan teori (Alifa, 2013), perusahaan membutuhkan pengamanan yang baik atas aktiva yang dimilikinya agar tidak terjadi hal-hal yang merugikan perusahaan seperti penyelewengan, kerusakan dan kehilangan yang dilakukan oleh pihak yang tidak bertanggung jawab, sehingga suatu perusahaan memerlukan sistem dan prosedur yang dapat menjamin terlaksananya aktivitas perusahaan secara efektif dan efisien yang diaplikasikan ke dalam sistem informasi akuntansi. Usaha yang perlu dilakukan untuk membantu menjaga keamanan harta perusahaan adalah menyusun sistem informasi akuntansi dengan mempertimbangkan prinsip-prinsip pengawasan internal untuk menghindari kecurangan yang 
dapat terjadi yang dapat mempengaruhi kelangsungan perusahaan.

Hasil penelitian ini sejalan dengan teori (Rosita, 2015), pada sistem penerimaan dan pengeluaran kas yang baik semua transaksi penerimaan dan pengeluaran dalam jumlah besar harus dilakukan dengan cek yaitu melalui bank, sedangkan untuk penerimaan dan pengeluaran tunai yang jumlahnya relatif kecil dilakukan melalui kas kecil. Kesalahan ataupun penyimpangan terhadap kas di tangan (kas kecil) biasanya melibatkan pihakpihak intern perusahaan terutama di bagian kas. Umumnya kasus-kasus penyimpangan tersebut terjadi karena sistem akuntansi yang diterapkan perusahaan tidak tepat dan kurang memadai"

Penelitian ini sejalan dengan penelitian Yusuf Maulana, Sudrajat Jajat (2014), berdasarkan hasil penelitian diketahui bahwa sistem informasi akuntansi penerimaan kas berpengaruh positif terhadap pengendalian intern pendapatan. Hal ini dapat dilihat dari besarnya koefisien korelasi yaitu 0,911 yang menunjukan bahwa adanya pengaruh yang sangat kuat antara sistem informasi akuntansi penerimaan kas (variabel $\mathrm{X}$ ) dan pengendalian intern pendapatan (variabel Y) pada Perum Damri. Dengan nilai koefisien determinasi sebesar $83 \%$ yang berarti pengaruh sistem informasi akuntansi penerimaan kas terhadap pengendalian intern pendapatan sebesar $83 \%$, dan sisanya sebesar $27 \%$ dipengaruhi oleh faktor lain yang ada di Perum DAMRI Bandung yang tidak dilakukan oleh peneliti.

Penelitian ini sejalan dengan penelitian Pujiono, Puspitasari, Sukarno (2016), menemukan bahwa variabel sistem pengendalian intern berpengaruh signifikan terhadap pengelolaan keuangan, Berdasarkan hasil uji validitas dan reliabilitas seperti disajikan dalam Tabel 5.5 menunjukkan bahwa nilai $\mathrm{t}$ (ditunjukkan oleh nilai C.R) untuk loading signifikansi 0,05 (nilai kritis $=1,96)$, demikian juga nilai probabilitasnya lebih kecil dari $\alpha(0,05)$. Sehingga dapat disimpulkan bahwa semua variabel secara signifikan berhubungan dengan konstruk (semua indikator valid). hal ini membuktikan bahwa dengan adanya sistem pengendalian intern yang sesuai dengan tujuan dalam memajukan pembangunan daerah maka akan meningkatkan pengelolaan keuangan daerah.

Penelitian ini sejalan dengan penelitian Fauzan (2018), menemukan bahwa variabel sistem pengendalian intern berpengaruh terhadap fungsi penerimaan kas, berdasarkan hasil pembahasan penelitian ini dapat disimpulkan yaitu sistem pengendalian intern terhadap fungsi penerimaan kas di PT BANK Muamalat Indonesia cabang pematangsiantar sudah dilaksanakan dengan baik, data penelitian ini menggunakan data penelitian berupa slip setoran 
dan laporan harian transaksi penerimaan kas serta dokumen yang berkaitan dengan fungsi penerimaan kas diperusahaan.

Penelitian ini sejalan dengan penelitian Sulasmini Ni Putu Eka, Herawati Nyoman Trisna, Sinarwati Ni Kadek (2014), hasil penelitian ini menunjukkan bahwa kegiatan pengendalian intern kas pada BUMD di Kabupaten Buleleng dijalankan pada setiap bagian yang tercermin dari pembagian tugas dan tanggungjawab dari masing-masing BUMD di Kabupaten Buleleng Begitu juga struktur organisasi yang disusun telah memisahkan tugas, kewajiban, wewenang, dan tanggungjawab tiap bagian walaupun masih ada BUMD yang belum melakukan pemisahan fungsi yang jelas terutama pada bagian pengawasan intern karena keterbatasan SDM yang dimiliki, pengendalian intern kas berpengaruh signifikan positif terhadap realisasi pencatatan penerimaan kas.

Penelitian ini sejalan dengan penelitian Kalumata, Nangoi B, Robert (2017), dengan hasil penelitian menyimpulkan bahwa sistem informasi akuntansi penjualan tunai yang ada pada PT. Hasjrat Abadi Cabang Malalayang Manado sistem otorisasi dan prosedur pencatatan penerimaan kas dari penjualan tunai diotorisasi oleh bagian kasir dengan mencatat kuitansi pelunasan. Pemesanan yang dilakukan oleh pelanggan diotorisasi oleh sales dengan membuat surat pemesanan kendaraan untuk penjualan, Pencatatan akuntansi telah dikerjakan oleh bagian administrasi dan pihak yang berwenang dan telah dilaksanakan pemisahan tugas oleh masing- masing bagian, dokumen yang digunakan sudah baik karena diotorisasi oleh bagian yang tepat. Dokumen yang digunakan telah mengunakan nomor urut tercetak dan sudah didesign dengan sangat baik oleh perusahaan. Penerapan penerimaan kas pada perusahaan PT. Hasjrat Abadi cabang malalayang manado sudah terorganisir dengan baik sistem otorisasi dan prosedur pencatatan penerimaan kas. Sistem otorisasi dan prosedur pencatatan, semua penerimaan order dari pembeli diotorisasi oleh salesman dan bertanggung jawab untuk membuat SPK.

Penelitian ini sejalan dengan penelitian Kaligis, Ilat, Pontoh (2015), dengan hasil penelitian Sistem Pengendalian Internal Kas yang diterapkan oleh Dinas Pendapatan Daerah Kota Bitung telah efektif dan memadai. Pemisahan tugas yang cukup yang dilakukan oleh Dinas Pendapatan Daerah Kota Bitung sudah efektif, dan Sistem dan prosedur yang dilaksanakan oleh Dinas Pendapatan Daerah Kota Bitung sudah efektif, karena telah memenuhi syarat sistem dan prosedur Pengendalian Internal.

Penelitian ini sejalan dengan penelitian Tatawi yefta palit, Saerang David Paul Elia, dan 
Afandi Dhullo (2015), dengan hasil penelitian ini menggunakan analisis deskriptif dalam bentuk studi kasus yang menggunakan metode wawancara dan dokumentasi dalam proses pengumpulan data. Hasil penelitian menunjukkan bahwa lingkungan pengendalian pada Dispenda Kota Bitung telah memadai ditinjau dari pemberian tugas dan tanggung jawab dalam melaksanakan kegiatan penerimaan kas yang baik perancangan dan penggunaan dokumen dan catatan yang memadai, perlindungan agar tidak terjadi penyelewengan dalam aktivitas penerimaan kas, pemeriksaan oleh pihak independen, pencatatan dan pelaporan penerimaan kas yang sudah memadai dapat dilihat dari formulir pendaftaran dan pendataan, jurnal umum penerimaan kas, buku besar, buku besar pembantu dan laporan pertanggungjawaban bendahara penerimaan. Secara keseluruhan, sistem dan prosedur penerimaan kas pada Dinas Pendapatan Kota Bitung sudah memadai dan sesuai dengan prosedur operasional standar yang berlaku.

Penelitian ini sejalan dengan penelitian Tandri Marchell, Sondakh J Jullie, Sabijono Harjanto (2015), adapun penerapan Sistem Pengendalian Intern terhadap penerimaan dan pengeluaran kas pada RSU Pancaran Kasih GMIM Manado pada dasarnya sudah cukup baik jika diamati, berikut jika dinilai berdasarkan elemen-elemen sistem pengendalian intern, lingkungan pengendalian, penilaian resiko, kegiatan pengendalian, komunikasi dan informasi, pemantauan.

Penelitian ini sejalan dengan penelitian Manengkey Mavolia Marchia, Tinangon J Jantje (2015), hasil penelitian dapat disimpulkan pelaksanaan sistem pengendalian intern penerimaan kas pada PT. Bank Rakyat Indonesia secara keseluruhan dilaksanakan dengan baik, hal ini ditandai dengan adanya pemisahan tugas, sistem pengamanan fisik kas yaitu uang kas yang ada di dalam kantor disimpan di dalam lemari besi yang dilengkapi dengan kunci kombinasi angka yang bersifat rahasia, pemeriksaan intern dilaksanakan secara insidentil dan laporan harian dibuat setiap hari kerja sehingga keadaan keuangan bank sehari- hari dapat diketahui. Prosedur penerimaan kas yang telah diterapkan Bank Rakyat Indonesia Unit Bahu Manado agar tetap dipertahankan dan jika memungkinkan ditingkatkan sesuai dengan perkembangan kegiatan dalam perusahaan.

Penelitian ini sejalan dengan penelitian Bahari Ivan Setyo, Dwiatmanto, Wi Endang Maria Goretti (2017), Berdasarkan dari hasil analisis, masih terdapat kelemahan pada sistem penjualan dan penerimaan kas. Diantaranya adalah perangkapan fungsi pada kas dan akuntansi, pada penjualan dan kredit, dokumen yang tidak efisien, serta penyetoran ke kas 
bank tidak langsung disetorkan pada hari yang sama. Dilihat dari hasil analisis, peneliti membrikan saran yaitu pemisahan fungsi antara fungsi kas dan akuntansi dilakukan administration and finace coordinator, pemisahan fungsi penjualan dan kredit dengan menugaskan koordinator after sales service, lebih efisien dokumen yang digunakan, dan langsuanag menyetorkan uang yang diterima pada hari yang sama. Hal ini dilakukan supaya sistem akuntansi penjualan dan penerimaan kas dapat menigkatkan pengendalian intern dan meminimalisir resiko penyelewengan maupun penggelapan.

Penelitian ini sejalan dengan penelitian Esteria Ni wayan, Sabijono Harijanto, Lambey Linda (2016), Hasil penelitian menunjukkan bahwa sistem akuntansi penerimaan dan pengeluaran kas telah berjalan dengan efektif dan sesuai prosedur yang ada yaitu terdapat otorisasi terhadap transaksi yang terjadi dari pihak yang berwenang, terdapat pemisahan fungsi dan mempunyai sistem pengendalian internal yang baik.

Penelitian ini sejalan dengan penelitian Afifah Natalia, Soebandhi Santirianingrum, Wardhana Rony (2014), hasil penelitian yang dilakukan oleh peneliti di PT GIS, kesimpulan yang dapat diambil adalah sistem pengendalian internal atas piutang belum berjalan sesuai dengan komponen sistem pengendalian internal yang dijelaskan dalam SPAP (Standar Profesional Akuntan Publik) SA seksi 319, Penelitian yang dilakukan Deftrianto, Saerang David P. E, Tangkuman J Steven (2018), dengan hasil penelitian Sistem pengendalian intern penerimaan kas pada hotel lucky inn sudah cukup efektif dan memadai dengan memenuhi lima unsur pengendalian intern yaitu, lingkungan pengendalian, penaksiran resiko, aktivitas pengendalian, informasi dan komunikasi, serta pemantauan. Hal ini ditandai dengan adanya pemisahan tugas, tanggung jawab dan batasan wewenang yang jelas pada setiap unit kerja yang terdapat pada perusahaan. Penelitian ini sejalan dengan penelitian Damayanti, M.Yusuf Hernandez (2018), Berdasarkan penelitian yang telah dilakukan maka dapat disimpulkan bahwa dengan adanya aplikasi sistem infromasi penerimaan dan pengeluaran kas pada KPRI Andan Jejama dapat memudahkan karyawan dalam pengelolaan data penerimaan kas dan pengeluaran kas, mempercepat dalam penyajian laporan dan mempermudah dalam proses pencarian data kas masuk dan kas keluar pada KPRI Andan Jejama Kabupaten Pesawaran sehingga dapat meningkatkan efektifitas dan efisiensi kerja.

Penelitian ini sejalan dengan penelitian Kurniawati Indah (2017), hasil penelitian menunjukkan masih terdapat kelemahan yang ditemukan peneliti pada sistem yang telah 
diterapkan. Adanya perangkapan tugas, yaitu fungsi operasi keuangan dan pencatatan, hal ini dilakukan oleh fungsi penjualan, fungsi gudang, dan fungsi pengiriman. Fungsi kasa dan fungsi jurnal dirangkap oleh fungsi penjualan. Dokumen yang digunakan hanya faktur penjualan tunai. Catatan akuntansi yang digunakan buku order penjualan, jurnal penjualan, dan kartu gudang. Prosedur yang digunakan adalah proedur order penjualan, prosedur penerimaan kas, prosedur penyerahan barang, dan prosedur pencatatan penjualan tunai.

Penelitian ini sejalan dengan penelitian Hudanantho Agus Nurul (2009), hasil penelitian dapat disimpulkan bahwa pada dasarnya Sistem Pengendalian Penerimaan Kas atas Penjualan Tunai pada KPRI Sejahtera, Bayan dapat dikatakan sudah cukup baik. Tetapi dengan masih terdapat beberapa prinsip dan unsur pengendalian intern yang belum terpenuhi yaitu tidak ada pemisahan tangung jawab yang jelas pada penerimaan kas tunai, tidak terdapat catatana kuntansi yang memadai, serta penerimaan karyawan yang tidak sesuai dengan pendidikan atau profesinya masing- masing dapat dijadikan bahan refleksi untuk meningkatkan kualitas Koperasi Pegawai Republik Indonesia, Bayan.

\section{PENUTUP}

\section{Simpulan}

Berdasarkan hasil analisis dan pembahasan yang telah dilakukan yaitu mengenai implementasi sistem pengendalian intern dan pengaruhnya terhadap penerimaan kas maka dapat diberikan kesimpulan sebagai berikut.

Sistem pengendalian intern mempunyai pengaruh positif dan signifikan terhadap penerimaan kas pada Perusahaan Air Minum Tirta Mangkaluku kota Palopo.

\section{Saran}

Berdasarkan hasil analisis, pembahasan, dan kesimpulan di atas, maka penulis memberikan beberapa saran yang dapat dikemukakan dalam penelitian ini adalah sebagai berikut:

Untuk meningkatkan sistem pengendalian intern maka setiap karyawan harus diberi pemahaman mengenai tugas dan tanggungjawab masing-masing serta komputer yang sudah ada lebih diperbarui agar lebih memudahkan aktivitas penerimaan kas.

Dalam penelitian ini penulis hanya meneliti tentang Implementasi sistem pengendalian intern dan pengaruhnya terhadap penerimaan kas secara teoritis masih banyak faktor-fakor yang 
dapat mempengaruhi penerimaan kas. Sehingga perlu diadakan penelitian lebih lanjut terhadap faktor-faktor lainnya yang mempengaruhi penerimaan kas yang tidak dieliti oleh penulis.

\section{DAFTAR PUSTAKA}

Afifah Natalia Nur dkk. 2015. Analisis Sistem Pengendalian Internal Atas Piutang Pada Pt Gis. e-Jurnal Spirit Pro Patria Vol.1 No.1 April 2015.

Alifa.F. Nur (2013),'Evaluasi Sistem Informasi Akuntansi Penjualan Dan Penerimaan Kas Dalam Upaya Meningkatkan Efektifitas Pengendalian Intern"Jurnal Adminsitrasi Bisnis Universitas Brawijaya.2(1) Hal-38

Arens, A.A. dan Loeblecke, J.K. 2001. Auditing Pendekatan Terpadu. Buku Satu. Edisi Bahasa Indonesia. Terjemahan Amir Abdi. Salemba Empat, Jakarta.

Bahari, Ivan setyo dkk. 2017. Analisis Sistem Akuntansi Penjualan Dan Penerimaan Kas Dalam Upaya Peningkatan Pengendalian Intern (Studi Pada Pt Sumber Purnama Sakti Motor Lamongan). Jurnal Administrasi Bisnis (JAB) Vol. 53 No. 1 Desember2017, (administrasibisnis.studentjournal.ub.ac.i d).

Baridwan, Zaki. 2013. Pengendalian intern : Erlangga. Jakarta

B. Romney, Marshall.,dan Paul John Steinbart. (2014) Sistem Informasi Akuntansi (Edisi k13). Jakarta: Penerbit Salemba Empat.

Bodnar, George., Hoopwood, William. 2006. Sistem Informasi Akuntansi Edisi 9. Penerbit Andi. Yogyakarta Committee of Sponsoring Organizations of the Treadway Commission. 1994. Internal Control - Integrated Framework. Two- Volume Edition.

Fauzan M. 2018. Sistem Pengendalian Intern Terhadap Fungsi Penerimaan Kas Pada Pt. Bank Muamalat Indonesia Cabang Pematangsiantar Jurnal Masharif al- Syariah: Jurnal Ekonomi dan Perbankan Syariah Vol. 3, No. 2, 2018

Hudanantho, Agus Nurul. 2009 Sistem Pengendalian Intern Penerimaan Kas Atas Penjualan Tunai Pada Koperasi Pegawai Republik Indonesia Sejahtera Bayan. Skripsi : Fakultas Ekonomi Universitas Negeri Semarang.

Hikmah, Noor; Chairina dan Rahmayanti, D. 2011.Faktor-Faktor Yang Mempengaruhi Luas Pengungkapan Corporate Governance Dalam Laporan Tahunan Perusahaan Perbankan Yang Terdaftar Di Bursa Efek Indonesia. Aceh : Simposium Nasional Akuntansi XIV. Hudanantho Agus Nurul. 2009. Sistem Pengendalian Intern Penerimaan Kas Atas Penjualan Tunai Pada Koperasi Pegawai Republik Indonesia Sejahtera Bayan. Jurnal Universitas Negeri Semarang

I Made Deftrianto, Leonardus dkk. 2018. Evaluasi Sistem Pengendalian Intern Penerimaan Kas Pada Hotel Lucky Inn Manado. Jurnal Riset Akuntansi Going Concern 13(1), 2018, 14-24.

Kalumata Novita dkk. 2017. Evaluasi Pengendalian Internal Sistem Informasi Akuntansi Penjualan Dan Penerimaan Kas Pada Pt. Hasjrat Abadi Cabang Malalayang Manado. Jurnal Riset Akuntansi Going Concern 12(2), 2017, 1205-1215.

Kaligis, Gabriella Margaretha dkk. 2015. Analisis Penerapan Sistem Pengendalian Intern Kas Pada Dinas Pendapatan Daerah Kota Bitung. Jurnal Berkala Ilmiah Efisiensi Volume 15 No. 04 Tahun 2015. 
Krismiaji. 2015. Sistem Informasi Akuntansi. Jogjakarta: Uup Stim Ykpn.

Lamusu, Lusiana. 2013. Pengaruh Sistem Pengendalian Intern Pemerintah terhadap Efektivitas Pengelolaan Keuangan Daerah pada DPPKAD Kabupaten Gorontalo. Jurnal Akuntansi, Universitas negeri Gorontalo.

Manengkey, Mavolia Marchia, dan J. Tinangon Jantje. 2015. Evaluasi Sistem Pengendalian Intern Penerimaan Kas Pada Pt. Bank Rakyat Indonesia (Persero) Tbk. Unit Bahu Manad. Jurnal EMBA Vol.3 No.2 Juni 2015, Hal. 938- 948, ISSN 2303-1174

Mulyadi. 2001 . Sistem Akuntansi : Salemba Empat. Jakarta.

Mulyadi, 2016. Sistem Akuntansi. Edisi Keempat. Salemba empat. Jakarta.Rai, Gusti Agung. 2008. Audit Kinerja Pada Sektor Publik: Konsep, Praktik, dan Studi Kasus. Jakarta: Salemba Empat.

Esteria Ni Wayan dkk. 2016. Analisis Sistem Akuntansi Penerimaan Dan Pengeluaran Kas Pada Pt. Hasjrat Abadi Manado. Jurnal Berkala Ilmiah Efisiensi, Vol 16 No. 04 Tahun 2016.

PP Nomor 60 Tahun 2008 Tentang Sistem Pengendalian Intern Pemerintah

Peraturan Daerah Kabupaten Luwu No. 12 Tahun 1985

Permendagri No. 4 Tahun 2008 Pedoman Pelaksanaan Review Atas Laporan Keuangan Daerah Pasal 1(10) Sistem pengendalian intern

Pujiono, Dodik Slamet dkk. 2016. Pengaruh Sistem Pengendalian Intern Terhadap Pengelolaan Keuangan Daerah Serta Kinerja Pemerintah Daerah (Studi Di Provinsi Maluku Utara). Jurnal Bisnis dan Manajemen. Vol. 10, No 1 Januari 2016 Hal. 68 81.

Puspitasari, Ayudia Dwi. 2017. Analisis Pengaruh Enterprise Risk Management Disclosure, Intellectual Capital Disclosure, dan Corporate Social Responsibility Disclosure Terhadap Nilai Perusahaan (Studi Empiris Pada Perusahaan Pertambangan yang Terdaftar di BEI Tahun 2012-2015).

Surat Keputusan Menteri Pekerjaan Umum Nomor: 66-KPTS-1991 tanggal 2 Desember 1991 tentang Penyerahan Pengelolaan Prasarana dan Sarana Penyediaan Air Bersih di Kabupaten Luwu Undang - Undang Dasar Negara Kesatuan Republik Indonesia tahun 1945. 1945. Indonesia.

Sapar. 2014. Pedoman Penulisan Skripsi. Palopo: Sekolah Tinggi Ilmu Ekonomi Muhammadiyah Palopo.

Sari, Parlina Iin, 2014. Analisa Sistem Informasi Akuntansi Penerimaan dan Pengeluaran Kas pada Fakultas Ilmu Sosial dan Ilmu Politik Universitas Sriwijawa. Skripsi. Universitas Palembang

SR, Soemarso. 2002. Akuntansi Suatu Pengantar ; Jakarta : Rineka Cipta.

Siti Kurnia Rahayu dan Ely Suhayati. 2009. Auditing Konsep dasar dan Pedoman Pemeriksaan Akuntan Publik: Graha Ilmu. Yogyakarta.

Sugiyono. 2013. "Metode Penelitian Administrasi”. Bandung: CV. ALFABETA 
Sugiyono. 2014. Metode Penelitian Pendidikan Pendekatan Kuantitatif, Kualitatif. Bandung: Alfabeta : Vol 4, No 9

Syarifudin, Yan S.H. (2010) Pelaksanaan Sistem Pengendalian Internal Untuk Mewujudkan Pengelolaan Keuangan Daerah Yang Efektif, Efisien Dan Bebas Korupsi. Jurnal Univertas Tanjung Pura.Vol 3 No.5 (2013).ISSN 0216/2091.

Reeve, J.M.,Waren,C.S., Jonathan, E.D., Ersa, T.W.,Gatot, S., Amir, A.J. \& Chaerul, D.D. 2013. Pengantar Akuntansi- Adaptasi Indonesia. Salemba Empat, Jakarta Sapar. 2017. Pengantar Metode Penelitian. Bogor: Maira Printing Plus.

Rosita, Ayu Ida, 2005. Sistem Akuntansi Penerimaan dan Pengeluaran Kas pada PT. Pelayaran Nasional Indonesia Cabang Semarang. Skripsi. Universitas Negeri Semarang.

Tatawi Yefta Palit dkk. 2015. Analisis Sistem Pengendalian Intern Pada Prosedurpenerimaan Kas Pajak Hotel Dan Pajak Reklame Pada Dinas Pendapatan Kota Bitung. Jurnal Berkala Ilmiah Efisiensi Volume 15 No. 05 Tahun 2015.

Tandri, Marchell dkk. 2015. Efektivitas Penerapan Sistem Pengendalian Intern Terhadap Penerimaan Dan Pengeluaran Kas Di Rsu Pancaran Kasih Gmim Manado. Jurnal EMBA Vol.3 No.3 Sept. 2015, Hal.208-218, ISSN 2303-11.

Undang-Undang Nomor 11 Tahun 2002 tentang Pembentukan Kabupaten Mamasa dan Kota Palopo di Provinsi Sulawesi Selatan.

Undang-Undang Republik Indonesia Nomor 23 Tahun 2014 tentang Pemerintah Daerah. 2014. Jakarta : Departemen Dalam Negeri Republik Indonesia.

Yusuf, Maulana dan Sudrajat, Jajat. 2014. Pengaruh Sistem Informasi Akuntansi Penerimaan Kas Terhadap Pengendalian Pendapatan Pada Perum Damri Bandung. Jurnal Ekonomi, Bisnis \& Entrepreneurship Vol. 8, No. 1, April 2014, ISSN 2443-0633.

Wilopo. 2006. Analisis Faktor-faktor yang Berpengaruh terhadap Kecenderungan Kecurangan Akuntansi (Studi pada Perusahaan Publik dan Badan Usaha Milik Negara di Indonesia). Simposium Nasional Akuntansi (SNA) 9.Padang, 23-26 Agustus 2006 